\title{
A RAPID SPECTROPHOTOMETRIC METHOD FOR DETERMINATION OF THIOBARBITURIC ACID REACTIVE SUBSTANCES IN RAINBOW TROUT FEED
}

\author{
Slađana M. Rakita*1, Dušica S. Čolović ${ }^{1}$, Alenka R. Levart ${ }^{2}$, Vojislav V. Banjac ${ }^{1}$, Radmilo R. Čolović ${ }^{1}$ \\ Danka M. Dragojlović ${ }^{\text {, }}$ Olivera M. Đuragić ${ }^{1}$ \\ ${ }^{1}$ University of Novi Sad, Institute of Food Technology, Bulevar cara Lazara 1, 21000 Novi Sad, \\ Serbia \\ ${ }^{2}$ University of Ljubljana, Biotechnical Faculty, Groblje 3, 1230 Domžale, Slovenia
}

*Corresponding author:
Phone: +381214853808
Fax: +38121450725
E-mail address: sladjana.rakita@fins.uns.ac.rs

ABSTRACT: Oxidative changes in fish feed during storage are a major problem in aquaculture nutrition. The current study aims to present fast and simple spectrometric method to measure thiobarbituric acid reactive substances (TBARS) in the commercial rainbow trout feeds without hydrolysis step, as a method for determination of lipid peroxidation. The proposed test was validated and relevant method characteristics which were evaluated within the validation protocol were: linearity (range), limit of detection, limit of quantification, precision (repeatability and intra-laboratory reproducibility), accuracy and method performance (X-and R-control charts). The obtained results indicated that presented TBARS test was linear in the range of $1.11-13.33 \mathrm{nmol} / \mathrm{mL}$ and precise under both repeatability and reproducibility test conditions. The method was characterized by acceptable accuracy considering low analyte concentration in the samples. The method also showed to be stable in terms of changes in the average level and variability. The results in the present work indicated that the proposed test could be successfully applied for TBARS quantification in rainbow trout feed for routine quality control in aquaculture sector, especially in case when need to analyse a great number of samples in a short time.

Key words: fish feed, thiobarbituric acid reactive substances, lipid peroxidation, method validation

\section{INTRODUCTION}

Contemporary aquaculture is one of the fastest growing food production sectors in the world. The latest trend in fish breeding is to use high level of fats in the diet, especially in Salmonids nutrition, where lipids represent a crucial source of energy. Commercial trout diets usually contain up to $17 \%$ of lipids, with significant amount of highly unsaturated fatty acids (Yildiz et al., 2015). These compounds are well known as one of the most susceptible to lipid peroxidation process. Lipid peroxidation is the major cause of quality loss in high fat foods and feeds, and increasing efforts has been devoted to monitor oxidative changes in food systems (Wold and Kvaal, 2000). Oxidative rancidity in diets containing oxidized fish oils could have negative effect on growth, feed intake and health in fish (Laohabanjong et al., 2009). Elevated dietary level of aldehydes can easily result in increased level of the same 
compounds in blood and tissue of fish, which increases the risk of pathological changes. Oxidized lipids can also cause reduction of antioxidant substances naturally present in fish tissue, leading to secondary antioxidant deficiency and consequently increase in vivo oxidative stress (Hamre et al., 2001). Trout feed has been increasingly produced by usage of blood meal, as a cheaper replacer of fish meal with constant availability on the market (Bahrevar and Faghani-Langroud, 2015). Blood meal contains $\mathrm{Fe}^{2+}$ ion from haemoglobin, which, in presence of $\mathrm{H}_{2} \mathrm{O}_{2}$, results in rapid generation of hydroxyl radical (Fenton reaction) and accelerate oxidation processes (lonescu and Poljsak, 2010). Therefore, it is necessary to constantly control oxidative changes in trout feed, especially during storage period.

Malondialdehyde (MDA), propanal, hexanal, and 4-hydroxynonenal are the most extensively studied secondary products of lipid peroxidation. MDA reacts easily with thiobarbituric acid (TBA) forming coloured complex; hence it has been widely used as a reliable biomarker for lipid peroxidation of omega- 3 and omega- 6 fatty acids (Ayala et al., 2014). TBA reactive substances (TBARS) can be detected by several high-pressure liquid chromatography (HPLC) methods (Seljeskog et al., 2006; Papastergiadis et al., 2012). However, due to the high cost, long time of analyses and required skilled operator, these methods are usually not applicable to routine controls. Thus, a simple method is required for application in serial control which can be carried out by both manufacturers, or specialized laboratories. Mendes et al. (2009) showed that spectrophotometric method can be reliable as HPLC method for determination of oxidative changes in fish. The main advantage of HPLC method in comparison with UV-Visible spectroscopy is higher sensitivity and specificity (Barriuso et al., 2013). On the other hand, spectrophotometric method is preferred for analysis of a large number of samples because it is simple, fast, and cheap. HPLC method also includes laborious experimental procedure and data processing (Barriuso et al., 2013), which is the main limitation in its application in every-day analysis. Botsoglou et al. (1994) described spectrometric method for the TBARS detection in animal tissues, food, and feed substances. However, the developed method involved hexane during extraction procedures, which could cause losses in the content of MDA. Another disadvantage of the method is involvement of hydrolysis step, which can be considered as an aggressive reaction and requires a trained analyst. Hydrolytic reaction usually leads to a huge heat release and, in some cases; it lasts too long, so other side reactions can occur (Hessel et al., 2006). Papastergiadis et al. (2012) developed similar method for determination of MDA content in different foods (meat products, cheese, dry nuts, potato crisps) and oils which involved different extraction techniques whereas food products rich in starch required enzymatic hydrolysis.

Considering all the exposed facts, the application of a simple method for TBARS measurement is of great importance for the whole chain of feed and food quality control. According to our knowledge, there is a lack of information on evaluating the efficiency of TBARS method for determining MDA concentration in fish feeds. Therefore, this paper aims to present a simple, fast and sensitive spectrometric method for the analysis of TBARS in the commercial rainbow trout feed without hydrolysis, which can be easily applied in every-day analyses. The fitness-for-purpose of TBARS assay was evaluated through method validation protocol.

\section{MATERIALS AND METHODS}

\section{Samples}

Fifteen extruded rainbow trout feed samples were purchased from local fish feed markets and used in this study. The storage period of the samples in the stores was not known. The samples were of different quality and had variable chemical composition (Table 1). Selected rainbow trout feed samples had fat content between 24.82 and $32.78 \%$, and protein content between $34.24 \%$ and $44.36 \%$. Crude fibre, moisture and ash content were in the range of $1.36-3.21 \%, 3.37-7.05 \%$, and $5.14-6.04 \%$, respectively. 
Table 1.

Chemical composition (\%) of selected rainbow trout feed samples

\begin{tabular}{lccccc}
\hline Sample & Crude fat & Crude protein & Crude fiber & Moisture & Ash \\
\hline 1 & 29.94 & 35.29 & 3.21 & 5.95 & 5.66 \\
2 & 32.78 & 37.79 & 2.61 & 5.78 & 5.81 \\
3 & 31.95 & 34.24 & 2.53 & 7.54 & 5.68 \\
4 & 31.38 & 39.16 & 2.16 & 4.78 & 5.80 \\
5 & 32.17 & 37.49 & 2.60 & 7.05 & 5.22 \\
6 & 28.73 & 39.34 & 2.88 & 6.27 & 5.71 \\
7 & 31.33 & 39.15 & 2.47 & 6.39 & 5.37 \\
8 & 30.72 & 36.27 & 3.04 & 5.18 & 5.14 \\
9 & 29.80 & 39.33 & 2.28 & 4.80 & 5.76 \\
10 & 24.82 & 44.36 & 1.36 & 3.37 & 6.04 \\
11 & 29.02 & 40.15 & 2.57 & 4.97 & 5.54 \\
12 & 31.24 & 38.31 & 2.16 & 5.63 & 5.68 \\
13 & 30.47 & 38.30 & 2.86 & 6.42 & 5.90 \\
14 & 26.96 & 41.58 & 1.75 & 3.72 & 5.96 \\
15 & 27.91 & 39.10 & 2.96 & 5.56 & 5.65 \\
\hline
\end{tabular}

\section{Chemicals and reagents}

1,1,3,3-tetramethoxypropane (TEP), 2thiobarbituric acid (TBA) and butylatedhydroxytoluene $(\mathrm{BHT})$ were purchased from Sigma-Aldrich (Steinheim, Germany).

Trichloroacetic acid (TCA) and methanol were purchased from PanReacAppliChem (Darmstadt, Germany). Ethanol (absolute grade, $\geq 99.8 \%$ ) was purchased from ZorkaPharma (Šabac, Serbia).

\section{Preparation of solutions and calibration standards}

For the purpose of preparing TBA solution $(0.6 \%), 300 \mathrm{mg}$ of TBA was weighed and quantitatively transferred to a beaker with approximately $45 \mathrm{~mL}$ of deionized water. The beaker was placed in an ultrasonic bath and heated to $60^{\circ} \mathrm{C}$. When TBA was dissolved, the solution was transferred to volumetric flask of $50 \mathrm{~mL}$ and filled with water to the mark. Fresh solution of TBA was prepared every day. BHT solution contained $400 \mathrm{mg} \mathrm{BHT}$ in $50 \mathrm{~mL}$ of methanol.

Standard solution of MDA $(8.33 \mathrm{mmol} / \mathrm{L})$ was prepared by transferring $200 \mu \mathrm{L}$ of TEP to $100 \mathrm{~mL}$ volumetric flask. The solution which was prepared by mixing ethanol and deionized water in ratio of 2:3 was taken into the flask until mark. Mixture of methanol and 5\% TCA (1:1.5) was used to dilute standard solution to stock solution
$(41.65 \mathrm{nmol} / \mathrm{mL})$. From the stock solution, different concentrations $(1.11,3.33,5.55$, $7.77,11.11$ and $13.33 \mathrm{nmol} / \mathrm{mL}$ ) of MDA were prepared. Standard MDA solutions $(0.75 \mathrm{~mL})$ were transferred to $10 \mathrm{~mL}$ test tubes and mixed with $0.6 \%$ TBA $(1.5 \mathrm{~mL})$. The tubes were tightly closed and heated in a water bath at $90{ }^{\circ} \mathrm{C}$ for 60 minutes. The tubes were then cooled at room temperature for 30 minutes and absorbance was read at $532 \mathrm{~nm}$ using a UVVisible spectrophotometer model SPECORD M40 (Carl Zeiss Jena, Germany). The calibration curve was constructed by plotting the absorbance values versus the concentration values. For each point of the calibration curve, 5 replicates were analysed according tothe above protocol.

\section{TBARS assay}

Determination of TBARS was performed according to methods of Tomažin et al. (2013) and Voljč et al. (2011), which were originally used for preparation of liver and meat samples. These methods were chosen as they showed good potential in preliminary analysis of fish feed. Since these samples differed in chemical composition in comparison to liver and meat samples, and different concentration of TBARS were expected, several modifications had to be included. Grinded rainbow trout feed samples $(0.1 \mathrm{~g})$ were mixed with $0.5 \mathrm{~mL}$ of $\mathrm{BHT}$ in a 2-mL Eppendorf micro centrifuge 
tubes to prevent autoxidation of the sample. Then, $0.75 \mathrm{~mL}$ of $5 \%$ TCA were added to the tubes, vortexed for $15 \mathrm{~min}$ and centrifuged for $15 \mathrm{~min}$ at $14.500 \mathrm{rpm}$ at $4{ }^{\circ} \mathrm{C}$. $0.75 \mathrm{~mL}$ of the supernatant was mixed with $1.5 \mathrm{~mL}$ of $0.6 \%$ TBA and heated at 90 ${ }^{\circ} \mathrm{C}$ for $60 \mathrm{~min}$. After cooling, the absorbance was read at $532 \mathrm{~nm}$. Results were calculated against the standard curve. The TBARS was calculated according to the following equation:

$$
\text { TBARS }\left(\frac{n m o l}{g}\right)=\frac{(A-b) \times V}{a \times m}(1)
$$

Where $A$ is an absorbance corresponding to the tested sample, $b$ is an intercept of the calibration curve, $a$ is a slope of the calibration curve, $m$ is weight of the sample, $V$ is a volume correction.

\section{Method validation}

The analytical method was validated according to the Decision 2002/657/ED (European Commission, 2002) in order to determine linearity (range), limit of detection (LOD), limit of quantification (LOQ), and precision (repeatability and intra-laboratory reproducibility). In addition, the accuracy and method performance were also evaluated. Linearity was studied in the range of $1.11-13.33 \mathrm{nmol} / \mathrm{mL}$. The calibration curve was constructed with seven concentrations of the standard stock solution $(41.65 \mathrm{nmol} / \mathrm{mL})$. The range of linearity was assessed by checking the linear regression coefficient $\left(R^{2}\right)$ of the calibration curve. The limit of detection (LOD) is defined as the lowest amount of an analyte in the sample that can be reliably detected but not quantified. The limit of quantification (LOQ) is the lowest concentration of an analyte in the sample that can be quantified with the acceptable accuracy and precision (Ullah et al., 2017). LOD was calculated as a standard deviation of ten consecutive measurements of a blank sample multiplied by the factor three (LOD $\left.=3 \times S D_{\text {blank }}\right)$. LOQ was calculated as a standard deviation of ten consecutive measurements of a blank sample multiplied by the factor ten $(\mathrm{LOQ}=$ $10 \times S_{\text {blank }}$ ) (Eurachem Guide, 1998). Precision of the method was evaluated at two levels: repeatability and reproducibility (intra-laboratory). Precision study was per- formed on selected rainbow trout feed samples: sample \#2, sample \#4 and sample\#8 (Table 2), which were characterized by low $(35.31 \mathrm{nmol} / \mathrm{g})$, mean $(85.32$ $\mathrm{nmol} / \mathrm{g})$ and high (113.17 nmol/g) TBARS concentration, respectively. Repeatability was performed by the same analyst, using the same chemicals, apparatus and within a single day in a short time. For that purpose, rainbow trout feed samples were successively tested ten times. Reproducibility was evaluated by analyzing the same samples within two different days by two analysts. For the quantitative expression of repeatability and reproducibility, corresponding relative standard deviations (RSDr and RSDR) of measured results were calculated. These values were compared with the expected values derived from the Horwitz equation (Horwitz, 2003:

$$
R S D=2^{1-0.5 \times \log c}(2)
$$

where $c$ is the measured concentration of the analyte in the sample, expressed as a mass fraction. The mass fraction was calculated by multiplying the molar concentration by the molecular weight of MDA (Watanabe et al., 2012b). The acceptability of the precision characteristics of a method was achieved by the use of HORRAT values (HORRATr and HORRATR), which gave a comparison between the actual precision and the precision predicted by the Horwitz equation (Watanabe et al., 2012b). If the HORRAT value is 2 or less, then the method could be considered to have satisfactory reproducibility values, whereas a value $>2$ usually indicates unsatisfactory performance of the method (Watanabe et al., 2012a).

Method accuracy was determined by recovery of a known amount of MDA standard solution added at the beginning of the assay. This was performed by adding the standard stock solution to the sample which was characterized by low TBARS amount (sample \#2, Table 2) at three different levels $(50,100$ and $150 \%$ of the concentration estimated in the sample) to cover a broad range of analyte concentrations (Gustavo Gonzáles et al., 2010).The accuracy was expressed as the 
ratio of the obtained amount in the recovered amount of TBARS to the calculated amount. This method characteristic was done in triplicate.

Stability of TBARS method was studied using X- and R-control charts. In the Xcontrol chart, the plotted values were the mean values of duplicates, whereas in the R-chart the plotted values corresponded to the percentage of difference between duplicates (Rakita et al., 2014). The central line $(C L)$, warning limits $(W L)$, and action limits $(A L)$ were calculated according to Wild and Seber (1999).

\section{Statistical analysis}

Mean values as well as standard deviations of the measured results were calculated in MS Excel.

\section{RESULTS AND DISCUSSION}

\section{TBARS concentration in rainbow trout feed}

To estimate the efficiency of the spectrophotometric TBARS assay for determination of MDA content in rainbow trout feeds, the samples were collected based on availability in local fish feed markets. The measured TBARS concentrations in the samples were presented in Table 2. The selected fish feed samples demonstrated a wide range of TBARS concentration. TBARS content of the samples varied between 35.31 and $113.17 \mathrm{nmol} / \mathrm{g}$, demonstrating the diversity of chosen samples regarding the concentration of secondary products of PUFA oxidation. Hevrøy et al. (2004) reported the concentration of TBARS in diet for Atlantic salmon being in the range of $47-86 \mathrm{nmol} / \mathrm{g}$, which is in agreement with our results, indicating comparable extent of lipid oxidation in fish feeds, available at the Serbian market. According to Hamre et al. (2001) TBARS values for medium and highly oxidized diets for Atlantic salmon were 61 and 76 $\mathrm{nmol} / \mathrm{g}$, respectively.

Heating step is requisite for releasing MDA from fatty acid hydroperoxides, in order to form complex with TBA. Since high reaction temperature can affect sample autoxidation and cause artificially high absorbance values, the inclusion of an an- tioxidant in the assay before boiling is essential. In this research, BHT was used as an antioxidant, because it was considered to be more effective in the protection of sample autoxidation than other commonly available antioxidants.

The application of spectrophotometric TBARS method for measurement of MDA concentration in biological systems has been a matter of considerable debate in the literature, due to the lack of specificity toward MDA (Du and Bramlage, 1992; Wang et al., 1997). The presence of interfering compounds in complex matrices could affect the accuracy of the test and cause unreliable results. However, precipitation by TCA enabled elimination of most of the potential MDA precursors (MDA-protein complexes or oxidized lipids) in the assay. Hindering compounds (amino acids, aldehydes and fatty acid hydroperoxides) which are present in deproteinized supernatant, and form complex with TBA, contribute to the colour development to a lesser extent. The absorption at $532 \mathrm{~nm}$ produced by TBApositive compounds is incomparably lower than the absorption produced by MDA. Therefore, the concentration of these compounds should be very high to interfere significantly with the formation of the TBA colour complex and affect results (Esterbauer and Cheeseman, 1990). Also, TBARS assay is more sensitive when fatty acids with more than two double bonds are present in high concentration, as is the case with fish feeds which contain fish (Papastergiadis et al., 2012). TBARS test is proven to be reliable when applied for MDA determination in fish products, since MDA was the major compound that reacted with TBA and formed coloured complex. Furthermore, acidic extraction of the sample yields higher TBARS values, because strong acidic conditions are essential for the release of protein bound MDA, and therefore, give better indication of bioavailable MDA in feeds (Mendes et al., 2009).

Data on measuring TBARS level in rainbow trout feeds are lacking. Since rainbow trout and salmon belong to the group of Salmonids, the feeds for their nutrition are very similar in nutrient and chemical com- 
position, and hence, the values of TBARS in these feeds are quite comparable. In other research, non-processed fish diet containing whole herring without any antioxidants had TBARS content less than $100 \mathrm{nmol} / \mathrm{g}$ of dry weight, while the same diet after heat treatment, freezing and storage for 18 weeks had TBARS content over $700 \mathrm{nmol} / \mathrm{g}$ of dry weight (Hamre et al., 2010).

\section{Validation of method for TBARS content determination}

The fitness-for-purpose of TBARS assay applied for routine testing is evaluated through method validation protocol. Partial validation was carried out to evaluate only performance characteristics which were relevant to the TBARS method. Therefore, linearity (range), limit of detection (LOD), limit of quantification (LOQ), precision (repeatability and reproducibility), and method performance were assessed within validation protocol (Rakita et al., 2014).

To assess linearity, calibration curve was constructed by plotting absorbance values read at $532 \mathrm{~nm}$ versus corresponding amount of TBARS. The absorbance values increased proportionally with the increment in the content of TBARS in the standard solutions (Figure 1). The obtained linear relationship can be presented with the following calibration equation:

$y=0.0918 \times x+0.0324(3)$

where $x$ is TBARS amount in $\mathrm{nmol} / \mathrm{mL}$. The linear regression equation showed a good linear relationship between the absorbance values and TBARS amount in the range of $1.11-13.33 \mathrm{nmol} / \mathrm{mL}$. The coefficient of determination $\left(R^{2}\right)$ obtained from the regression curve was 0.9992, being highly significant for the assay. The linearity of the calibration curve is considered acceptable when $R^{2}>0.995$ (Beljkaš et al., 2010).

Standard deviations of ten successively analysed blank samples were used to calculate LOD and LOQ. LOD as the lowest concentration of TBARS in a sample that can be detected with reasonable statistical certainty was found to be 0.509 $\mathrm{nmol} / \mathrm{mL}$. LOQ as the lowest concentration of TBARS that can be quantified was determined to be $1.208 \mathrm{nmol} / \mathrm{mL}$.

The acceptability of the precision characteristics of the test was assessed using the HORRAT values, which give a comparison of the actual precision with the precision predicted by the Horwitz equation (Watanabe et al., 2012b). Precision parameters of TBARS method were presented in Table 3. Repeatability was evaluated by quantifying TBARS concentration within intra-day conditions. HORRATr value for the concentration of $35.31 \mathrm{nmol} / \mathrm{g}$ was 0.57 , that for concentration of $85.32 \mathrm{nmol} / \mathrm{g}$ was 0.40 , and that for concentration of $113.17 \mathrm{nmol} / \mathrm{g}$ was 0.68 . The obtained HORRATr values, which were less than 1 , indicate routine repeatability of the assay that exceeds what would be predicted and considered acceptable based on the analyte concentration (Horwitz, 2003). Repeatability of this method was higher than reported method for determination of TBARS in various foods (Zeb and Ullah, 2016). Theoretical repeatability measure $(\mathrm{RSDr}, \mathrm{H})$ is generally one half to two-thirds of the reproducibility measure RSDR,H (Horwitz, 2003). The obtained higher values of RSDr and RSDR calculated from Horwitz equations are expected at very low concentration of the analyte (Taverniers et al., 2004). Method reproducibility was determined by analysing the same samples within two days by two different analysts. HORRATR values for TBARS concentrations of $35.31,85.32$ and $113.17 \mathrm{nmol} / \mathrm{g}$ were $0.61,0.52$ and 0.75 , respectively. It could be observed that all the HORRATR values were less than 2 , which showed that the performance reproducibility criterion was achieved, and therefore validity of the method reproducibility was confirmed (Rakita et al., 2014). As already mentioned, TBA solution was prepared fresh every day before the analysis, which had a great effect on the method reproducibility.

\section{Accuracy}

Accuracy is the percent of analyte recovered by the method from a known added amount. Recovery depends largely on the sample preparation, matrix as well as on 
the analyte concentration (Tavernies et al., 2004). Obtained recovery values ranged between 71.5 and $76.6 \%$ (Table 3), which, considering the analyte concentration, were acceptable according to recovery rates as outlined by the AOAC Peer Verified Methods program (AOAC Interna- tional, 2000). As it could be observed, recovery increased with the increase in the concentration level of MDA added to the sample. Generally lower recovery values are probably the consequence of low TBARS concentration present in the sample.

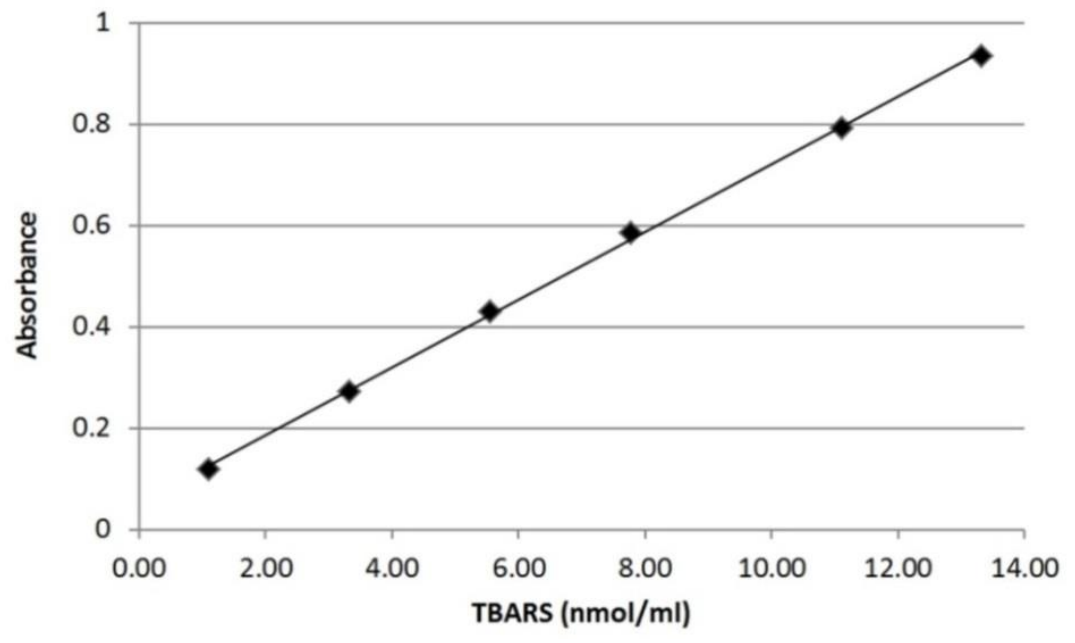

Figure 1. A calibration curve for TBARS method by spectrophotometric technique

Table 2.

Mean $( \pm S D)$ TBARS concentration in rainbow trout feed samples

\begin{tabular}{lcc}
\hline Samples & $\begin{array}{c}\text { TBARS concentration } \mathbf{( n m o l} / \mathbf{g}) \\
\text { Mean }^{*}\end{array}$ & SD \\
\hline 1 & 39.75 & 1.26 \\
2 & 35.31 & 1.53 \\
3 & 75.69 & 1.84 \\
4 & 85.32 & 0.61 \\
5 & 39.58 & 1.62 \\
6 & 99.23 & 2.45 \\
7 & 40.22 & 0.86 \\
8 & 113.17 & 2.79 \\
9 & 96.86 & 1.69 \\
10 & 70.10 & 0.32 \\
11 & 55.07 & 1.22 \\
12 & 92.15 & 1.76 \\
13 & 104.47 & 2.93 \\
14 & 63.67 & 0.79 \\
15 & 47.87 & 0.50 \\
\hline
\end{tabular}

*Values are the average of three replications

Table 3.

Precision characteristics of TBARS method

\begin{tabular}{ccccccc}
\hline MDA & \multicolumn{3}{c}{ Repeatability } & \multicolumn{3}{c}{ Reproducibility } \\
\cline { 2 - 7 } (nmol/g) & $\mathbf{R S D}_{\mathbf{r}}(\%)$ & RSD $_{\mathbf{r}, \mathrm{H}}(\%)$ & HORRAT $_{\mathbf{r}}$ & RSD $_{\mathbf{R}}(\%)$ & RSD $_{\mathrm{R}, \mathrm{H}}(\mathbf{\%})$ & HORRAT $_{\mathbf{R}}$ \\
\hline 35.31 & 5.31 & 9.31 & 0.57 & 8.67 & 13.91 & 0.61 \\
85.32 & 3.27 & 8.15 & 0.40 & 6.27 & 12.14 & 0.52 \\
113.17 & 5.24 & 7.75 & 0.68 & 8.79 & 11.55 & 0.75 \\
\hline
\end{tabular}

$R S D_{r}$ - repeatability relative standard deviation; $R S D r, H-$ Horwitz repeatability relative standard deviation; $R S D_{R}$ - reproducibility relative standard deviation; $R S D_{R, H}$ - Horwitz reproducibility relative standard deviation; $H O R R A T_{r}=R S D_{r} / R S D_{r}, H ; H O R R A T_{R}=R S D_{R} / R S D_{R}, H$ 
Table 4.

Accuracy of the spectrophotometric TBARS method

\begin{tabular}{ccc}
\hline $\begin{array}{c}\text { Amount present in the sample } \\
\text { (nmol/g) }\end{array}$ & $\begin{array}{c}\text { Level of addition } \\
\text { (\%) }\end{array}$ & $\begin{array}{c}\text { Recovery }^{*} \\
(\%)\end{array}$ \\
\hline 35.31 & 50 & 71.5 \\
35.31 & 100 & 74.8 \\
35.31 & 150 & 76.6 \\
\hline
\end{tabular}

${ }^{*}$ Values are the average of three replications
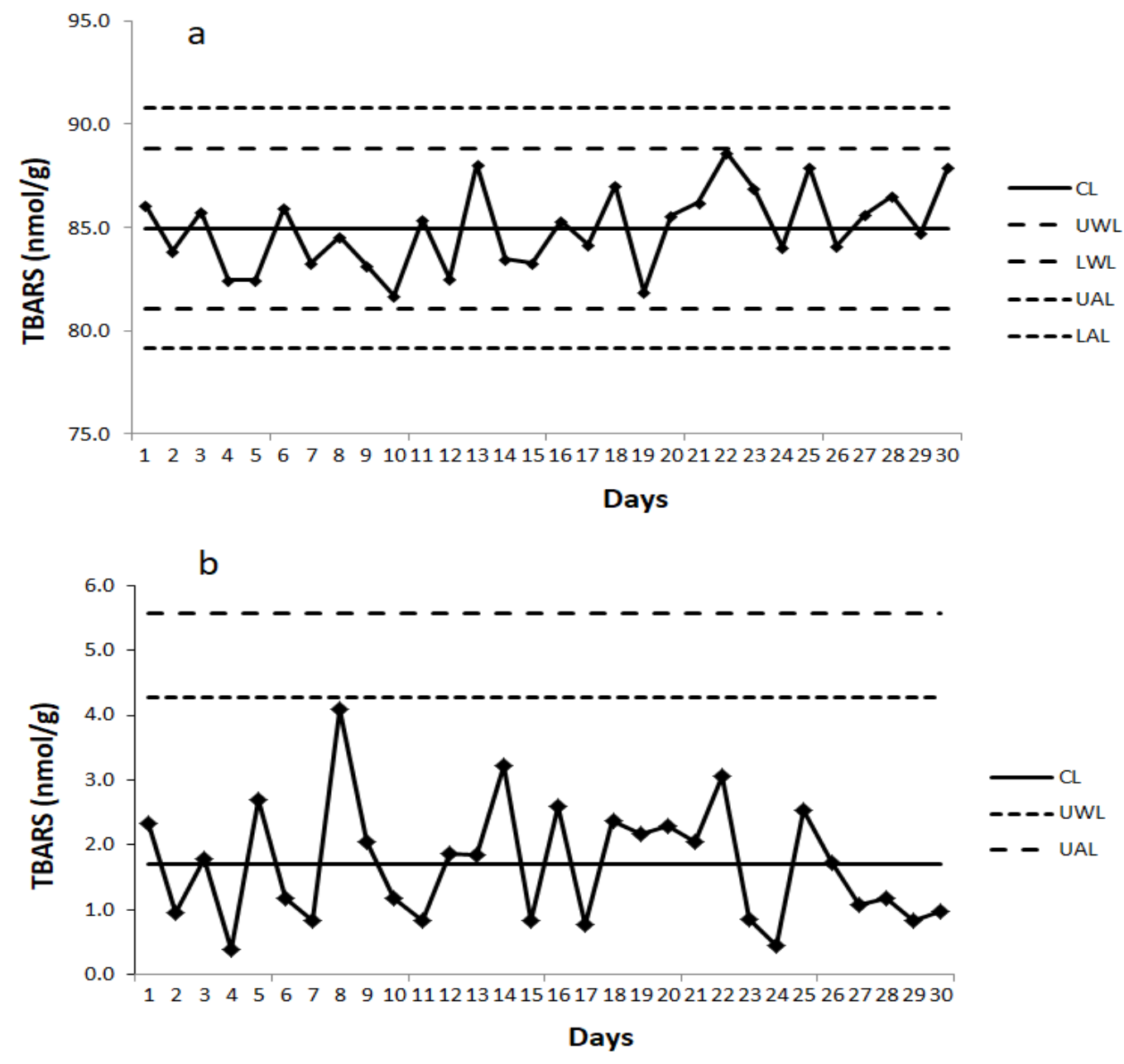

Figure 2. X- (a) and R-control chart (b) for TBARS method (CL, central line; UWL, upper warning limit; LWL, lower warning limit; UAL, upper action limit; LAL, lower action limit)

The obtained recovery was lower in comparison to spectrophotometric TBARS method applied in food product (Zeb and Ullah, 2016), but similar to traditional TBARS assay reported by Mendes et al. (2009), who determined recovery of 66$71 \%$ in fish samples.

Accidental variations of the experimental conditions could have significant effect on the TBARS method, leading to results out of expectation. X- and R- control charts were chosen to monitor the analytical stability of TBARS test during time period of
30 days (Figure 2). X-control chart was used to monitor the changes in the average level of a control sample, while $\mathrm{R}$ control chart was used to monitor changes in differences between replicates of test samples. If the actual results are within the action limits of the control charts, the results obtained for the sample can be accepted and method is stable.

On the other hand, if the results are out of the action limits, the test is not stable and action is necessary to find the cause. Concerning X-control chart, the results lied 
between 81.06 (lower warning limit) and $88.84 \mathrm{nmol} / \mathrm{g}$ (upper warning limit) (Figure $2 a)$. All the values were located within the war-ninglimits, which indicated that the me-thod was under control. In the R-control chart, the obtained results were positioned below upper warning limit of 4.27 $\mathrm{nmol} / \mathrm{g}$ (Figure $2 \mathrm{~b}$ ). An analytical method is considered under control if no more than $5 \%$ of the measured values exceed the warning limits (Taverniers et al., 2004). Therefore, the presented results indicated that TBARS test could be considered as a stable method with regard to changes in the average level and variability.

\section{CONCLUSIONS}

The present study was carried out to modify and evaluate simple and fast spectrophotometric method for the measurement of thiobarbituric acid reactive substances in rainbow trout feeds. It was observed that TBARS test showed good linearity in the range of $1.11-13.33 \mathrm{nmol} / \mathrm{mL}$, whereas both method repeatability and reproducibility were acceptable based on the HORRAT values. When tested method accuracy, the recovery was acceptable considering low analyte concentration in the tested samples. Moreover, the presented method showed to be of a long-term stability both in terms of changes in variability and the average level. The obtained results indicated that proposed test could successfully be employed for fast quantification of TBARS in rainbow trout feeds for routine quality control in aquaculture, especially when needed to test a great number of feed samples. Data on determination of TBARS concentration in fish feed are rather scarce, and there is a need for more extensive examination considering significance of lipid peroxidation in fish nutrition. Further investigation should be conducted in order to determine allowed upper levels of TBARS in fish feed, or permissible limits of similar significant oxidation parameters for distinction between oxidized and not oxidized samples.

\section{ACKNOWLEDGEMENTS}

This research was financially supported by the Ministry of Education, Science and Technological Development, Republic of
Serbia (Project number III46012, contract number 451-03-68/2020-14/200222).

\section{REFERENCES}

1. AOAC International (2000). Method Validation Programs (OMA/PVM Department), including Appendix D: Guidelines for collaborative study procedures to validate characteristics of a method of analysis.

http://www.aoac.org/aoac prod imis/AOAC Do cs/StandardsDevelopment/Collaborative Study Validation Guidelines.pdf

2. Ayala, A., Muñoz, M.F., Argüelles, S. (2014). Lipid peroxidation: Production, metabolism, and signaling mechanisms of malondialdehyde and 4-hydroxy-2-nonenal. Oxidative Medicine and Cellular Longevity, 2014, 360438 (31 pp).

3. Bahrevar, R., Faghani-Langroudi, H. (2015). Effect of fish meal replacement by blood meal in fingerling rainbow trout (Oncorhynchus mykiss) on growth and body/ fillet quality traits. Aquaculture, Aquarium, Conservation \& Legislation-International Journal of the Bioflux Society, 8 (1), 34-39.

4. Barriuso, B., Astiasaran, I., Ansorena, D. (2013). A review of analytical methods measuring lipid oxidation status in foods: a challenging task. European Food Research and Technology, 236, 1-15.

5. Beljkaš, B., Matić, J., Milovanović, I., Jovanov, P., Mišan, A., Šarić, Lj. (2010). Rapid method for determination of protein content in cereals and oilseeds: Validation, measurement uncertainty and comparison with the Kjeldalh method. Accreditation and Quality Assurance, 15, 555-561.

6. Botsoglou, N.A, Fletouris, D.J., Papageorgiou, G.E., Vassilopoulos, V.N., Mantis, A.J., Trakatellis, A.G. (1994). Rapid, sensitive, and specific thiobarbituric acid method for measuring lipid peroxidation in animal tissue, food, and feedstuff samples. Journal of Agriculture and Food Chemistry, 42 (9), 1931-1937.

7. Esterbauer, H., Cheeseman K.H. (1990). Determination of aldehydic lipid peroxidation products: malonaldehyde and 4-hydroxynonenal. Methods in Enzymology, 186, 407-421.

8. Eurachem Guide (2014). The fitness for purpose of analytical methods. A laboratory guide to method validation and related topics, LGC, Teddington, Middlesex, UK.

9. European Commission (2002). Commission decision 2002/657/EC of 12 August 2002 implementing Council Directive 96/23/EC concerning the performance of analytical methods and the interpretation of results. Official Journal of the European Union, L221, 8-36.

10. Gustavo González, A., ÁngelesHerrador, M., Asuero, A.G. (2010).Intra-laboratory assessment of method accuracy (trueness and precision) by using validation standards. Talanta, 82 1995-1998.

11. Hamre, K., Kolås, K., Sandnes, K., Julshamn, K., Kiessling, A. (2001). Feed intake and ab- 
sorption of lipid oxidation products in Atlantic salmon (Salmo salar) fed diets coated with oxidised fish oil. Fish Physiology and Biochemistry, 25, 209-219.

12. Hamre, K., Kolås, K., Sandnes, K. (2010). Protection of fish feed, made directly from marine raw materials, with natural antioxidants. Food Chemistry, 119 (1), 270-278.

13. Hessel, V. Hardt, S., Löwe, H. (2006). Chemical micro process engineering: Fundamentals, modelling and reactions. John Wiley \& Sons, New Jersey, US.

14. Hevrøy, E.M., Sandnes, K., Hemre, G.-I. (2004). Growth, feed utilisation, appetite and health in Atlantic salmon (Salmo salar L.) fed a new type of high lipid fish meal, Sea Grain $®$, processed from various pelagic marine fish species. Aquaculture, 235 (1-4), 371-392.

15. Horwitz, W. (2003). Validation: An invisible component of measurement. AOAC International, Gaithersburg, MD.

16. Ionescu, J.G., Poljsak, B. (2010). Metal ions mediated pro-oxidative reactions with vitamin C: Possible implications for treatment of differrent malignancies. International Journal of Cancer Prevention, 3 (3), 149-174.

17. Laohabanjong, R., Tantikitti, C., Benjakul, S., Supamattaya, K., Boonyaratpalin, M. (2009). Lipid oxidation in fish meal stored under different conditions on growth, feed efficiency and hepatopancreatic cells of black tiger shrimp (Penaeusmonodon). Aquaculture, 286 (3-4), 283-289.

18. Mendes, R., Cardoso, C., Pestana, C. (2009). Measurement of malondialdehyde in fish: A comparison study between HPLC methods and the traditional spectrophotometric test. Food Chemistry, 112 (4), 1038-1045.

19. Papastergiadis, A., Mubiru, E., Van Langenhove, H., De Meulenaer, B. (2012). Malondialdehyde measurement in oxidized foods: Evaluation of the spectrophotometric thiobarbituric acid reactive substances (TBARS) test in various foods. Journal of Agriculture and Food Chemistry, 60 (38), 9589-9594.

20. Rakita, S., Pojić, M., Tomić, J., Torbica, A. (2014). Determination of free sulphydryl groups in wheat gluten under the influence of different time and temperature of incubation: Method validation. Food Chemistry, 150 (1)s, 166-173.

21. Seljeskog, E., Hervig, T., Mansoor, M. A. (2006). A novel HPLC method for the measurement of thiobarbituric acid reactive substances (TBARS). A comparison with a commercially available kit. Clinical Biochemistry, 39 (9), 947-954.

22. Taverniers, I., De Loose, $M$. and Van
Bockstaele, E. (2004). Trends in quality in the analytical laboratory. II. Analytical method validation and quality assurance. Trends in Analytical Chemistry, 23 (8), 535-552.

23. Tomažin, U., Frankič, T., Voljč, M., Rezar, V., Levart, A., Salobir, J. (2013). The potency of $\alpha$ and $y$-tocopherol, and their combination, in reducing dietary induced oxidative stress in vivo and improving meat lipid stability in broilers. European Poultry Science, 77 (4), 266-274.

24. Voljč, M., Frankič, T., Levart, A., Nemec, M., Salobir, J. (2011). Evaluation of different vitamin $E$ recommendations and bioactivity of $\alpha-$ tocopherol isomers in broiler nutrition by measuring oxidative stress in vivo and the oxidative stability of meat. Poultry Science, 90, 14781488.

25. Ullah, A.K.M.A., Maksud, M.A. Khan, S.R. Lutfa, L.N., Quraishi, S.B. (2017). Development and validation of a GF-AAS method and its application for the trace level determination of $\mathrm{Pb}$, $\mathrm{Cd}$, and $\mathrm{Cr}$ in fish feed samples commonly used in the hatcheries of Bangladesh. Journal of Analytical Science and Technology, 8 (15), 1-7.

26. Watanabe, J., Oki, T., Takebayashi, J., Yamasaki, K., Takano-Ishikawa, Y., Hino, A., Yasui, A. (2012a). Method validation by interlaboratory studies of improved hydrophilic oxygen radical absorbance capacity methods for the determination of antioxidant capacities of antioxidant solutions and food extracts. Analytical Sciences, 28 (2), 159-165.

27. Watanabe, J., Takebayashi, J., Takano-Ishikawa, Y., Yasui, A. (2012b). Evaluation of a method to quantify quercetinaglycone in onion (Allium cepa) by single- and multi-laboratory validation studies. Analytical Sciences, 28 (12), 1179-1182.

28. Wild, C.J., Seber, G.A.F. (1999). Chance encounters: A first course in data analysis and inference. John Wiley \& Sons, New York, US.

29. Wold, J., Kvaal, K. (2000). Mapping lipid oxidation in chicken meat by multispectral imaging of autofluorescence. Applied Spectroscopy, 54 (6), 900-909.

30. Yildiz, M., Köse, I., Issa, G., Kahraman, T. (2015). Effect of different plant oils on growth performance, fatty acid composition and flesh quality of rainbow trout (Oncorhynchus mykiss). Aquaculture Research, 46 (12), 2885-2896.

31. Zeb, A., Ullah, F. (2016). A simple spectrophotometric method for the determination of thiobarbituric acid reactive substances in fried fast foods. Journal of Analytical Methods in Chemistry, 2016, 9412767 (5 pp). 


\title{
БРЗА СПЕКТРОФОТОМЕТРИЈСКА МЕТОДА ЗА ОДРЕЪИВАЊЕ РЕАКТИВНИХ СУПСТАНЦИ ТИОБАРБИТУРНЕ КИСЕЛИНЕ (ТБАРС) У ХРАНИ ЗА КАЛИФОРНИЈСКЕ ПАСТРМКЕ
}

\author{
Слађана М. Ракита ${ }^{1}$, Душица С. Чоловић ${ }^{1}$, Аленка Р. Леварт${ }^{2}$, Војислав В. Бањац ${ }^{1}$, Радмило Р. \\ Чоловић ${ }^{1}$, Данка М. Драгојловић ${ }^{1}$, Оливера М. Ђурагић ${ }^{1}$ \\ ${ }^{1}$ Универзитет у НовомСаду, Научни институт за прехрамбене технологије у Новом Саду, \\ 21000 Нови Сад, Булевар цара Лазара 1, Србија \\ ${ }^{2}$ Универзитет у љубљани, Биотехнички фракултет, 1230 Домжале, Гробље 3, Словенија
}

Сажетак: Оксидативне промене у храни за рибе настале током складиштења представљају велики проблем у исхрани риба. Ово истраживање има за циљ да представи брзу и једноставну методу за одређивање реактивних супстанци тиобарбитурнекиселине (ТБАРС) без хидролизе у комерцијалној храни за калифорнијеске пастрмке, као методу за одређивање липидне пероксидације. Метода је валидована и испитане су следеће карактеристике: линеарност (опсег), граница детекције, граница квантификације, прецизност (поновљивост и унутар лабораторијска репродуктивност), тачност и стабилност методе (X- и R- контролне карте). Приказани резултати указују да је ТБАРС метода линеарна у опсегу $1.11-13.33 \mathrm{nmol} / \mathrm{mL}$ и прецизна у условима поновљивости и унутар лабораторијске репродуктивности. С обзиром на малу концентрацију аналита у узорку метода је показала задовољавајућу тачност. Такође, метода је стабилна у погледу променљивости средњих вредности мерења и разлика између мерења. Резултати добијени овим истраживањем су указали да се ова метода може успешно применити за одређивање ТБАРС-а у храни за калифорнијске пастрмке током рутинске контроле квалитета у аквакултури када је потребно анализирати велики број узорака за кратко време.

Кључнеречи: храна за рибе, реактивне супстанце тиобарбитурне киселине, липидна пероксидација, валидација методе

Accepted: 2 March 2020

Received in revised form: 8 April 2020

Accepted: 12 May 2020 